\title{
QUALITY OF QUAIL EGGS AT DIFFERENT TIMES OF STORAGE
}

\author{
RAFAel CARlos NepomuCEnO ${ }^{1}$, Pedro HenRiQue WATANABE ${ }^{2}$, EdNARdo Rodrigues \\ Freitas $^{2}$, CARlos Eduardo Braga CruZ ${ }^{1}$, Maria Simone Mendes PeIXoto ${ }^{3}$, Mayara \\ LEMOS DE SOUSA ${ }^{3}$
}

\footnotetext{
1Pós-graduandos da Universidade Federal do Ceará - PDIZ, Fortaleza, CE, Brasil. rafael@zootecnista.com.br ${ }^{2}$ Professores Doutores da Universidade Federal do Ceará, Fortaleza, CE, Brasil.

${ }^{3}$ Graduandas em Zootecnia da Universidade Federal do Ceará, Fortaleza, CE, Brasil.
}

ABSTRACT

\begin{abstract}
A trial was conducted to evaluate quality of quail eggs from two companies (A and B) at two storage times (5 and 15 days after packing). A total of 480 eggs were kept at room temperature and distributed in a completely randomized design in $2 \times 2$ factorial arrangement (companies and storage time). The results indicated that trays from company B presented higher weight, as well as mean egg weight. However, the eggs in trays from company A showed greater uniformity. Evaluating the external quality, we found that above $90 \%$ of eggshell were considered with total integrity, and no difference for
\end{abstract}

this characteristic between companies was found. The eggs from company A presented lower average weight in comparison to those from company $\mathrm{B}$, regarding storage time. No differences were observed between eggs from companies A and B for Haugh unit value. Storage time of 15 days after packing promoted reduction in Haugh unit value in comparison to those stored for 5 days. Quail eggs from company A presented lower variation in weight, although heavier eggs are produced by company B. Internal quality of quail eggs from both companies was similar. Storage time affected eggs quality.

KEYWORDS: eggs standardization; Haugh unit value; shell integrity.

\section{QUALIDADE DE OVOS DE CODORNA EM DIFERENTES TEMPOS DE ARMAZENAMENTO}

\section{RESUMO}

O estudo foi conduzido para avaliar a qualidade de ovos de codorna de duas empresas (A e B) em dois tempos de armazenamento (5 e 15 dias após data de embalagem). Um total de 480 ovos foram mantidos em temperatura ambiente e distribuídos em delineamento inteiramente casualizado em esquema fatorial $2 \times 2$ (empresas e tempo de armazenamento). Os resultados indicam que as bandejas de ovos da companhia B apresentaram maior peso, como também no peso médio dos ovos. No entanto, os ovos em bandejas da empresa A apresentou maior uniformidade. Avaliando-se a qualidade externa, foi observada que acima de $90 \%$ dos ovos apresentaram cascas com total integridade, e não houve diferença para esta característica entre as empresas. Os ovos da empresa A apresentaram peso médio menor em comparação com os da empresa B, indenpendente do tempo de armazenamento. Não foram observadas diferenças entre os ovos de empresas A e B para valores de unidade Haugh. O tempo de armazenamento de 15 dias após a embalagem promoveu a redução nos valores de unidade 
Haugh em relação aos armazenados por 5 dias. Ovos de codorna da empresa A apresentaram menor variação de peso, embora os ovos da empresa B tenham apresentado maior peso. Os ovos de ambas as empresas apresentaram mais de $90 \%$ de ovos com integridade total da casca. A qualidade interna de ovos de codorna de ambas as empresas foram semelhantes, apesar do tempo de armazenamento ter afetado as características qualitativas dos mesmos.

PALAVRAS-CHAVE: Integridade da casca; padronização dos ovos; unidades Haugh.

\section{INTRODUCTION}

The quail egg is considered a nutritive food for human consumption, being one of the best and most economical sources of high quality protein, since its composition meets the most essential amino acids, as well as vitamins, minerals and fatty acids requirements ${ }^{1}$. However, for the nutritional potential of quail egg remain totally available for human consumption, the egg must be preserved during the storing period, since it may take weeks between the time of laying and its acquisition and preparation; thus, the greater this period, the worse the internal quality of the eggs, since they depreciate continuously after laying.

Several studies have shown that the deterioration of chicken and quail eggs at room temperature is greater than when refrigerated ${ }^{2,3}$. In this sense, cooling is the primary means of conserving the egg internal quality ${ }^{4}, 5$. However, Brazilian law does not require that eggs are kept under refrigeration, being most of them stored in sales markets at room temperature, and, in some cases, they are only cooled at consumers' home.

The process of depreciation or loss of egg internal quality usually occurs in function of decomposition of carbonic acid into carbon dioxide and water. As carbon dioxide is led to the outside in function of porosity of the eggshell, the remaining water promotes the liquefaction of albumen, causing an increase in $\mathrm{pH}$, leading to a dissociation process with protein complexion. In addition to increasing the size of the air chamber, the yolk also undergoes changes becoming wider and having a weakened membrane. This process leads to a deterioration of flavor and odor of the egg ${ }^{6}$.

The egg becomes improper for consumption when the yolk unites at one end or laterally, or when there is disruption of the vitelline membrane and the albumen and yolk are mixed ${ }^{7}$. It may happen to eggs due to changes resulting from aging, microbial deterioration, dehydration of the cuticle that seals the pores of the shell, and shrinkage by increasing the porosity of the shell to air and microorganisms.

To certify egg quality for sale, it is necessary to subject them to inspection by an official organ, which, in Brazil, is required by the Regulation of
Industrial and Sanitary Inspection of Animal Products (Regulamento de Inspeção Industrial e Sanitária de Produtos de Origem Animal RIISPOA) that operates inspecting establishments and producers $^{8}$. Furthermore, the Ministry of Agriculture, Livestock and Food Supply (Ministério da Agricultura Pecuária e Abastecimento - MAPA) regulates all legislation on egg for consumption, although there is no mention of quail eggs quality, being the classification specific for chicken eggs. The objective of this study was to evaluate the quality of quail eggs from two different companies at two storage times.

\section{MATERIAL AND METHODS}

We used 480 quail eggs from two companies (Company A; Company B) at two storage times (5 and 15 days after packaging). The eggs were distributed in a completely randomized design in a $2 \times 2$ factorial arrangement, considering the two companies and two storage times, totaling four treatments with four replicates of 30 eggs per experimental unit. For company selection, we previously visited the supermarkets and chose the two quail eggs companies that were present in most establishments.

We randomly selected two egg trays from each company in eight supermarkets in the city of Fortaleza, a purchase based on the registration list of supermarkets and hypermarkets, selected with the aid of the Unit of Health Surveillance (Célula de Vigilância Sanitária - CEVISA) of the municipality. All eggs were stored at room temperature in the same type of packaging (plastic tray for 30 eggs).

The eggs were purchased and analyzed at 5 and 15 days after packaging, and stored at $27.8 \pm 1.9$ ${ }^{\circ} \mathrm{C}$ during the study until analysis. The trays were identified according to the treatment, and the eggs were numbered. We verified standardization by weighing the eggs of each tray, using an electronic scale accurate to $0.01 \mathrm{~g}$, and obtained the weight of the eggs in the tray by the sum of weights of their respective eggs.

To evaluate external quality, we individually analyzed and classified the eggs, according to the integrity of the shell, following the following 
criterion: intact - when the shell was free of defects; dirty - when adhered dirt was detected in the shell; bitten - when there were fissures and cracks in the shell; and broken - when the shell was broken.

For the evaluation of the internal quality, we measured egg weight, specific gravity, Haugh unit value, percentage of yolk, albumen and shell, shell thickness and $\mathrm{pH}$ of yolk and albumen. The specific gravity was determined according to Freitas et al. ${ }^{9}$, and Haugh units value according to Alleoni and Antunes ${ }^{10}$. After determining the height of the albumen, egg yolk was separated from the albumen and weighed in the $0.01 \mathrm{~g}$ accuracy balance. The percent yolk was obtained by the ratio between the yolk and the egg weight. To quantify the percentage of shell, eggshells were separated, washed and dried at room temperature for 48 hours, obtaining the ratio between the shell and egg weight. The percentage of albumen was determined according to the equation: $\%$ albumen $=100-(\%$ yolk $\%+$ shell $)$. The shell thickness was measured using a digital caliper at $0.01 \mathrm{~mm}$ precision, considering the average of apical, equatorial and basal zones. The $\mathrm{pH}$ of albumen and yolk was measured with a composite sample of ten eggs per experimental unit, using a benchtop pH meter, model Q-400AS.

Data on the integrity of the shell were tabulated and converted to percentage of defects and the percentage of classes undergoing radical transformation $(\sqrt{\mathrm{X}+1})$ to meet the premises of analysis of variance. All data were subjected to analysis of variance and compared by $\mathrm{F}$ test at $5 \%$ probability.

\section{RESULTS AND DISCUSSION}

The assays results indicated that egg trays from company B presented higher weight as well as mean egg weight in comparison to company A (Table 1). However, the eggs from company A showed greater uniformity, with less egg weight variation. According to Murakami et al. ${ }^{11}$, the variation of egg quail weight is between 10 to $11 \mathrm{~g}$, considering the deviation from 7 to $14 \mathrm{~g}$. In Brazil, there is no legal regulation to classify quail eggs, so based on deviation, the eggs from both companies were within the range considered as normal.

Table 1 - Weight of eggs in the tray and egg weight of two quail egg companies

\begin{tabular}{lcc}
\hline Company & Weight of eggs in the tray $(\mathrm{g})$ & Egg weight $(\mathrm{g})$ \\
\hline $\mathrm{A}$ & $314.52^{*}$ & $10.49 \pm 0.74^{*}$ \\
$\mathrm{~B}$ & $331.52^{*}$ & $11.05 \pm 1.01^{*}$ \\
\hline $\mathrm{CV}(\%)^{1}$ & 1.63 & 1.63 \\
\hline
\end{tabular}

${ }^{1}$ Coefficient of variation; * Significant effect on $\mathrm{F}$ test $(\mathrm{P}<0.05)$.

By evaluating the external aspects of quail eggs, we found that above $90 \%$ of eggshell presented total integrity, and there was no difference for this characteristic between companies (Table 2). Considering eggshell defects, some percentage of dirt and broken eggshell was found in eggs from both companies; however, company B presented higher amount of cracked eggshells. The quantity of defects in eggshells found in the present study showed failures in cleaning and sanitization procedures, due to the presence of excreta in eggshell, impairing the visual appearance of the product besides the risks of microbiological contamination, which would compromise the quality of other eggs in the tray, mainly those with broken or cracked eggshell.

Table 2 - Frequency of shell integrity aspects (\%) and average transformed frequency (ATF) of two quail egg companies

\begin{tabular}{lllllllll}
\hline \multirow{2}{*}{ Company } & Intact & & Dirty & & Cracked & \multicolumn{3}{c}{ Broken } \\
\cline { 2 - 9 } & \% & ATF & \% & ATF & \% & ATF & \% & ATF \\
\hline A & 93.75 & 9.73 & 4.58 & 2.13 & 0.83 & $1.23^{*}$ & 0.83 & 1.28 \\
B & 92.50 & 9.66 & 2.50 & 1.78 & 4.59 & $2.16^{*}$ & 0.42 & 1.14 \\
\hline CV $(\%)^{1}$ & 2.64 & & 48.05 & & 50.63 & & 37.56 & \\
\hline
\end{tabular}

${ }^{1}$ Coefficient of variation; * Significant effect on $\mathrm{F}$ test $(\mathrm{P}<0.05)$. 
Table 3. Quality of quail eggs from two companies at 5 and 15 days after packaging

\begin{tabular}{|c|c|c|c|c|c|c|c|c|}
\hline \multirow{2}{*}{ Variables } & \multicolumn{2}{|c|}{ Company (C) } & \multirow{2}{*}{$\begin{array}{l}\text { Time } \\
(\mathrm{T})\end{array}$} & \multirow{2}{*}{$\begin{array}{c}\text { post-packaging } \\
15 \text { days }\end{array}$} & \multicolumn{3}{|c|}{ Effects - ANOVA } & \multirow{2}{*}{$\mathrm{CV}(\%)^{1}$} \\
\hline & A & B & & & $\mathrm{C}$ & $\mathrm{T}$ & $\mathrm{C} \times \mathrm{T}$ & \\
\hline Egg weight (g) & 10.48 & 11.05 & 10.81 & 10.73 & $*$ & NS & NS & 8.37 \\
\hline Yolk (\%) & 35.92 & 35.47 & 35.60 & 35.79 & NS & NS & NS & 8.70 \\
\hline Albumen (\%) & 55.59 & 56.16 & 56.02 & 55.72 & $* *$ & NS & NS & 5.64 \\
\hline Shell (\%) & 8.50 & 8.37 & 8.38 & 8.49 & $* *$ & NS & NS & 7.13 \\
\hline Shell thickness (mm) & 0.157 & 0.153 & 0.156 & 0.154 & $*$ & NS & NS & 10.64 \\
\hline Specific Gravity & 1.0476 & 1.0557 & 1.056 & 1.048 & $*$ & $*$ & $*$ & 1.36 \\
\hline Haugh unit value & 76.54 & 76.74 & 77.80 & 75.48 & NS & $*$ & NS & 5.22 \\
\hline $\mathrm{pH}$ of yolk & 6.75 & 6.58 & 6.54 & 6.79 & NS & $*$ & NS & 4.31 \\
\hline $\mathrm{pH}$ of albumen & 10.26 & 10.25 & 10.25 & 10.26 & NS & NS & NS & 0.52 \\
\hline
\end{tabular}

${ }^{1}$ Coefficient of variation; NS - Non-significant; * Significant effect on F test $(\mathrm{P}<0.01)$; ** Significant effect on $\mathrm{F}$ test $(\mathrm{P}<0.05)$.

No differences were found in yolk percentage in eggs from both companies, although eggs from company A showed lower albumen percentage but higher eggshell percentage and thickness. The difference in albumen percentage found could be related to the breeding system adopted by the producer, since aspects as nutrition and age of birds can influence the egg weight and its composition. Storage time, as well as temperature and humidity can affect egg weight, however the period from 5 to 15 days after packing did not affect weight and percentage of yolk and albumen of eggs in room temperature. According to Yannakopoulos and Tserveni-Gousi ${ }^{13}$, quail eggs present higher thickness of eggshell membrane in comparison to laying hen eggs, and this structure could be responsible to reduce the loss of water and gases and consequently weight of eggs (Table3).

Although no effect of storage time of eggs on yolk percentage was noted in the present study, Santos et al. $^{7}$ observed an increase of this egg component, stating that storing can increase the permeability of vitteline membrane, allowing water content of albumen in egg yolk. Lemos et al. ${ }^{14}$ also stated that eggshell thickness can vary due to the level of egg production by quail, observing thinner eggshell by birds in high egg production system. Others factors as nutritional management, genetics, age and health conditions of birds can also affect eggshell quality.

For egg internal quality, those from company B presented greater specific gravity in comparison to eggs from company A. We also observed the effect of storing, noting low values for eggs after 15 days of packing. Specific gravity can be related to eggshell resistance ${ }^{15}$, and to the size of the air chamber, in a way that greater the specific gravity, lower the air chamber, and higher is the resistance of the eggshell. For both periods, eggs of company B presented higher values for specific gravity, indicating lower air chamber and consequently reduction in carbonic dioxide decomposition and slower depreciation.

We verified no differences $d$ between eggs from companies A and B for Haugh unit value; however, storage time affected this parameter. Albumen undergoes amino acids hydrolysis, promoting the destruction of protein structure, causing fluidization and impairment of vittellinic membrane, loss of viscosity and consequently a decrease in albumen height ${ }^{16}$, once this process depends on time and temperature of storage ${ }^{17-19}$. Although the classification of egg quality based on Haugh unit value considers as excellent those eggs with values above 72 , we observed that storage time of 15 days after packing promotes reduction in comparison to those stored for 5 days. Santos et al. ${ }^{7}$ and Souza and Souza ${ }^{20}$ observed the same effect of storage time on the reduction of Haugh unit value in quail eggs under room temperature. Extended storage also affects other quality parameters of eggs, decreasing albumen density ${ }^{7}$ and increasing $\mathrm{pH}$ of egg yolk $3,10,21$, due to higher permeability of yolk membrane to ions. According to Yannakopoulos and Tserveni-Gousi ${ }^{13}$, the membrane thickness in quail eggs is higher than those in laying hen eggs, resulting in smaller loss of moisture and gases. Therefore, the losses of carbonic dioxide after dissociation of carbonic acid are reduced and no effect in albumen $\mathrm{pH}$ was observed.

\section{CONCLUSIONS}

Quail eggs from company A presented lower variation in weight, although heavier eggs are produced by company B. Eggs from both companies 
presented more than $90 \%$ of eggs with total integrity, but failures in cleaning and sanitization procedures were found. Internal quality of quail eggs from both companies was similar. Storage time affected eggs.

\section{REFERENCES}

1. Moura GS, Barreto SLT, Lanna EAT. Efeito da redução da densidade energética de dietas sobre as características do ovo de codorna japonesa. Revista Brasileira de Zootecnia. 2010; 39(6): 1266-1271.

2. Moura AMA, Oliveira NTE, Thiebaut JTL, Melo TV. Efeito da temperatura de estocagem e do tipo de embalagem sobre a qualidade interna de ovos de codornas japonesas (Coturnix japonica). Ciência e Agrotecnologia. 2008; 32(2): 578-582.

3. Xavier IMC, Cançado SV, Figueiredo TC, Lara LJC, Lana AMQ, Souza MR, Baião NC. Qualidade de ovos de consumo submetidos a diferentes condições de armazenamento. Arquivo Brasileiro de Medicina Veterinária e Zootecnia. 2008; 60(4): 953-959.

4. Barbosa NAA, Sakomura NK, Mendonça MO, Freitas ER, Fernandes JBK. Qualidade de ovos comerciais provenientes de poedeiras comerciais armazenados sob diferentes tempos e condições de ambientes. ARS Veterinaria. 2008; 24(2): 122-133.

5. Figueiredo TC, Cançado SV, Viegas RP, Rêgo IOP, Lara LJC, Souza MR, Baião NC. Qualidade de ovos comerciais submetidos a diferentes condições de armazenamento. Arquivo Brasileiro de Medicina Veterinária e Zootecnia. 2011; 63(3): 712-720.

6. Rodrigues KRM, Salay E. Atitudes de granjeiros, atacadistas, varejistas e consumidores em relação à qualidade sanitária do ovo de galinha in natura. Revista de Nutrição. 2001; 14(3): 185-193.

7. Santos MSV, Espíndola GB, Lôbo RNB, Freitas ER, Guerra JLL, Santos ABE. Efeito da temperatura e estocagem em ovos. Ciência e Tecnologia de Alimentos. 2009; 29(3): 513-517.

8. BRASIL. MINISTÉRIO DA AGRICULTURA, PECUÁRIA E ABASTECIMENTO. Regulamento de Inspeção Industrial e Sanitária de Produtos de Origem Animal. Decreto no 30.691 de 29 de março de 1952, e alterações. DOU. Brasília, 1997. Avaliable from: http://www.planalto.gov.br/ccivil_03/decreto/19501969/D30691.htm

9. Freitas ER, Sakomura NK, Gonzalez MM, Barbosa NAA. Comparação de métodos de determinação da gravidade específica de ovos de poedeiras comerciais. Pesquisa Agropecuária Brasileira. 2004; 39(20): 509-512.

10. Alleoni AN, Antunes AJ. Unidade Haugh como medida de qualidade de ovos de galinha armazenados sob refrigeração. Scientia Agricola. 2001; 58(4) 681-685.

11. Murakami AE, Barriviera VA, Scapinello C, Valério SR. Efeito da temperatura e do período de armazenamento sobre a qualidade interna do ovo de codorna japonesa (Coturnix coturnix japonica) para consumo humano. Revista Unimar. 1994; 16(suplemento 1): 13-25.

12. Baptista RF, Koech KP, Ribeiro ROR, Mársico ET, Mano SB. Influência do trincamento da casca do ovo sobre sua qualidade comercial. Revista Brasileira de Ciência Avícola. 2007; 14(1): 35-38.

13. Yannakopoulos AL, Tserveni-Gousi AS. Quality characteristics of quail eggs. British Poultry Science. 1986; 27 (issue 2):171-176.

14. Lemos MJ, Calixto LFL, Fernandez IB, Melo IA, Souza DS. Peso, percentual e espessura de casca de ovos de codornas japonesas na faixa etária de 6 a 18 semanas. Revista Academica - Ciências Agrárias e Ambientais. 2012; 10(2): 183-188.

15. Abdallah AG, Harms RH, El-Husseiny O. Various methods of measuring shell quality in relation to percentage of cracked eggs. Poultry Science, v.72, p.20382043, 1993.

16. Rocha JSR, Barbosa VM, Lara LJC, Baião NC, Cançado SV, Lana AMQ, Pompeu MA, Vasconcelos RJC, Machado ALC, Miranda DJA, Fernandes MNS, Mendes PMM. Efeito do armazenamento e da cantaxantina dietética sobre a qualidade do ovo fértil e o desenvolvimento embrionário. Arquivo Brasileiro de Medicina Veterinária e Zootecnia. 2013; 65(3): 792-800.

17. Seleim MA, El-Prince E. Effect of storage and boiling on some quality characteristics of eggs. Assiut Journal of Agricultural Sciences. 2000; 31(4): 1-15.

18. Scott TA, Silversides FG. The effect of storage and strain of hen on egg quality. Poultry Science. 2000; 79: 1725-1729.

19. Carvalho FBC, Stringhini JH, Jardim Filho RM, Leandro NSM, Padua JT, Deus HASB. Influência da conservação e do período de armazenamento sobre a qualidade interna e de casca de ovos comerciais. Revista Brasileira de Ciência Avícola. 2003; suplemento 5: 100.

20. Souza HBA, Souza PA. Efeito da temperatura de estocagem sobre a qualidade interna de ovos de codorna armazenados durante 21 dias. Alimentos e Nutrição. 1995; 6: 7-13.

Ahn, BY, Kim JW, Lee YBI. Studies on the quality of locally produced eggs during marketing and distribution. II. Effects of washing treatment and storage temperature on egg quality. Korean Journal of Animal Science. 1991; 23(2): 92-96.

Protocolado em: 10 maio 2013. Aceito em 17 set. 2014. 